\title{
Modern methods in Structural Geology and Tectonics: a series of articles in honour of Martin Burkhard (1957-2006)
}

\author{
Stefan M. Schmid ${ }^{*}, 1$, Neil Mancktelow ${ }^{2}$, Jon $_{\text {Mosar }}^{3}$, O. Adrian Pfiffner ${ }^{4}, \&$ Jean-Paul Schaer ${ }^{5}$
}

Key words: Structural Geology, Tectonics, Burkhard, Alps, Jura, Neuchâtel

\section{ABSTRACT}

We briefly report on the conference held in May 2007 in honour of Martin Burkhard in Neuchâtel. We also present a short account of the achievements of this prominent scientist and teacher by selectively citing some of his work and briefly introduce the series of articles presented here, which represent a tribute to Martin Burkhard. We also add a complete list of publications by Martin Burkhard and co-workers.

\section{The Martin Burkhard Conference in Neuchâtel from May 11-13, 2007}

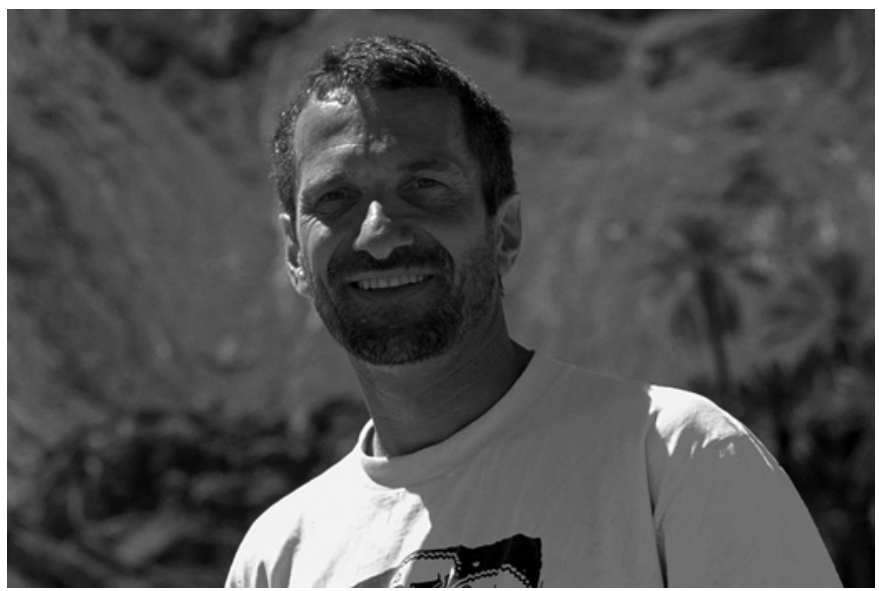

Fig. 1.

After the tragic death of Martin Burkhard (Fig. 1) some of his colleagues spontaneously decided to hold a conference in his honour at his home university in Neuchâtel. Consequently, the Swiss Geological Society, the Swiss Tectonics Studies Group, and the Institut de Géologie et d'Hydrogéologie at the Univer- sity of Neuchâtel organized a conference in honour of Martin Burkhard and his scientific work.

Logistic support for the conference was provided by Angelika Kalt and her staff at Neuchâtel University while the scientific sessions were organized by Neil Mancktelow (ETH Zürich), Jon Mosar (Fribourg), Adrian Pfiffner (Bern) and Stefan Schmid (Basel), mostly by invitation of well-known scientists from all over the world, all of whom were colleagues known to have closely cooperated with Martin.

The contributions at the conference were grouped into four main topics that many of us believe were Martin's favourite topics, being aware that his interests were much broader: (1) The role of fluids during deformation of the earth's crust, (2) Thick-skinned versus thin-skinned tectonics: type examples and controversies, (3) Neotectonics, seismotectonics, seismic hazard and uplift, and (4) Deformation mechanisms in carbonate rocks.

The conference started with a series of presentations honouring Martin Burkhard's achievements. The Vice-Rector for research at Neuchâtel University, Prof. Hans Beck, the Dean of the Science Faculty, Prof. Thomas Ward, the president of the Geological Society of Switzerland, Prof. Stefan Schmid, and two colleagues of Martin from the Institut de Géologie et d'Hydrogéologie, Prof. Jean-Paul Schaer and Prof. Karl Föllmi, emphasized the many merits of a great scientist and colleague.

\footnotetext{
${ }^{1}$ Geological-Paleontological Institute, Universität Basel, Bernoullistrasse 32, CH-4056 Basel.

${ }^{2}$ Neil Manktelow, Geologisches Institut, ETH Zentrum, CH-8092 Zürich.

${ }^{3}$ Jon Mosar, Ch. du Musée 6, CH-1700 Fribourg Switzerland.

${ }^{4}$ Adrian Pfiffner, Institut für Geologie der Universität Bern, Baltzerstrasse 1-3, CH-3012 Bern.

${ }^{5}$ Jean-Paul Schaer, Institut de Géologie et d'Hydrogéologie, Rue Emile-Argand 11, Case postale 158, 2009 Neuchâtel.

*Corresponding author: Stefan M. Schmid. E-mail: Stefan.Schmid@unibas.ch
} 
This was followed by 23 oral contributions, most of them of review type, given by renowned colleagues from Belgium, Canada, Germany, France, Great Britain, Italy, The Netherlands and Switzerland. A number of Martin's students enriched the scientific contributions with attractive poster exhibits. After two full days of scientific contributions, the participants felt that they had witnessed a conference of exceptional quality. Some of these contributions can be downloaded via the homepage of the Swiss Geological Society.

\section{Martin Burkhard as a scientist}

Martin Burkhard first learned the techniques of Structural Geology with John Ramsay at ETH Zürich, where he graduated with a diploma in 1981. He then undertook a PhD study under the guidance of Jean-Paul Schaer and Adrian Pfiffner at Neuchâtel University, a study that initiated important work on some of his favourite topics: Alpine Tectonics and the Helvetic nappes in particular, together with microstructural studies on carbonate rocks that shed light on deformation mechanisms. After graduating with a $\mathrm{PhD}$ in 1986 , he spent time as a postdoc at the University of Western Ontario (Canada), working on fluid-rock interaction during rock deformation under the guidance of Bill Fyfe and Rob Kerrick. He returned to Neuchâtel in 1988 where he was appointed chef de traveaux. In October 1993 he succeeded Prof. J.-P. Schaer and was nominated professor at Neuchâtel University.

Martin was a very active scientist who was involved in a total of 21 projects of the Swiss Science Foundation during his unfortunately short career. He supervised $10 \mathrm{PhD}$ students, 37 master and diploma students and was an external jury member at $24 \mathrm{PhD}$ exams.

Besides acting as a University teacher and researcher, he also actively engaged himself in a number of activities of direct relevance to society. To mention just a few, he was a member of the Commission on Nuclear Waste Disposal (since 2004), an expert in PEGASOS Seismic Hazard Nuclear Power Plants (2000-2004), president of the Coordination Romande Sciences de la Terre (2003-2004) and, last but not least, president of the Swiss Geological Society (1998-2000).

His publication record is not only characterized by a fascinating variety of topics but also by his close cooperation with numerous colleagues: he published 49 peer-reviewed articles with 54 different co-authors. Below we highlight just a few of his key-contributions.

His $\mathrm{PhD}$ work on the Helvetic nappes of the Swiss Alps resulted in an article on the tectonic and metamorphic evolution of the Helvetic nappes of Switzerland (Burkhard 1988). Particularly his series of profiles, illustrating the tectonic and metamorphic evolution from 40 Ma to present (Fig. 16 in Burkhard 1988) became a classic illustration, used ever since by many teachers in Alpine Geology and Tectonics.

Soon he also started to include the Jura Mountains and the Molasse Basin in his considerations of Alpine Tectonics, providing very inspiring insights into the kinematics of the Jura-
Alps system. One landmark paper on this topic specifically addressed the transfer of displacements from the Alps to the Jura Mountains via the Molasse Basin (Burkhard 1990) and the formation of the arcuate shape of the Jura Mountains. This is a topic he also addressed again much later, together with one of his students (Hindle et al. 2000). A second important paper on this topic is that by Burkhard \& Sommaruga (1998), which treats the Jura-Alps system on a crustal scale by integrating results from seismic reflection profiling and chrono-stratigraphical data into a coherent evolutionary scheme.

Interestingly, it is one of Martin's papers on the microfabric of naturally deformed calcite rocks that so far represents his most cited paper (Burkhard 1993). This contribution discusses the significance of twinning for measuring stress and /or strain during natural deformation. It also describes microstructural differences with increasing grade of metamorphism and is illustrated by high-quality micrographs.

It is to Martin's great merit that he made many of us aware of the importance of fluid-rock-interaction during thrusting along the famous Glarus Thrust. The work he undertook with one of his PhD students (Badertscher et al. 2002) nicely illustrates the use of geochemical tracing of fluid circulation by using stable isotopes, a topic he started to work on much earlier and especially during his stay in Canada (Burkhard \& Kerrich 1988).

Martin was also fascinated by the comparison of the thickskinned deformation he studied in the Anti-Atlas with the thinskinned deformation characteristic of the Jura Mountains. By working in Marocco, he followed a long tradition of Neuchâtel University initiated by his predecessor Jean-Paul Schaer. The work on this area also serves as an example of Martin's gift for presenting particularly enlightening and esthetically pleasing graphics (see, for example, Burkhard et al. 2006, his Fig. 6), a gift that helped him to transmit his enthusiasm for geology to students and colleagues alike.

Martin's most recent pet topic probably was that related to neotectonics and earthquake hazard. Together with Christian Sue he recently supervised a series of $\mathrm{PhD}$ students working on this topic and closely cooperated with many colleagues active in seismology and seismic hazard assessment. The paper by Delacou et al. (2004), addressing present-day geodynamics along the Western Alpine Arc, is a beautiful example of the important contribution he and his Neuchâtel team made in understanding what is actually going on at present in the Alps and their forelands.

By selectively referring to some of the work of Martin Burkhard and co-workers we hope to also encourage young geologists to read Martin's pioneering articles. We know that Martin loved to actively and enthusiastically interact with colleagues and students, and he keeps doing that through his written works.

\section{Martin as a teacher}

Martin was a gifted teacher, a very good communicator, a leader of great integrity and a good friend for all those with an interest

246 S. M. Schmid et al. 
in geology who lived in or passed through Neuchâtel. He made this subject great. All those who heard him speak fell under the spell of his enthusiasm and his ability to convince anyone that earth science was an important and fascinating subject in our changing world. Those who knew him most valued Martin's generosity, humanity, and his love for freedom and open spaces. His lectures had a reputation for excitement, charm and fun despite their solid scientific grounding. He did all he could to promote public understanding of science, working across disciplinary boundaries to integrate physical, chemical and biological perspectives and to look at their consequences for humanity and the world as a whole.

Martin brought out the best in his students by providing intellectual stimulation and support, but left them with enough freedom to be independently creative. Students and collaborators enjoyed the warmth of the friendly atmosphere he created. His open door was a constant invitation for a good cup of coffee, for a little chat or for a more serious scientific discussion.

Through his work and his character Martin helped to put a small department on the map as a respected institution. His lively nature and his stream of ideas never failed to stimulate optimism, accompanied by a lucid view of the benefits and perspectives that his activity could bring to his students and the local community. His death left a deep void at Neuchâtel University: the political authorities, which "profited" from his death, killed a two-centuries long glorious tradition in geology. We can only hope that Martin's seeds that he fostered with great care will eventually bring back his spirit for the study of basic and fundamental earth science in Neuchâtel and at other universities, where applied and/or environmental geosciences presently expand at the expense of a solid education in earth sciences for purely political reasons.

\section{Remarks regarding the series of articles presented in honour of Martin Burkhard in this issue of the Swiss Journal of Geosciences}

We received a total of 12 contributions, in part from the speakers at the Martin Burkhard conference and in part from former co-workers of Martin Burkhard, including some of his students. The first two papers discuss the role of fluids during deformation along the Glarus Thrust (Hürzeler \& Abart 2008) and results from recent age dating of shear zone activity in the Grimsel area of the Alps (Challandes et al. 2008).

This is followed by a discussion concerning the Alps-Jura system, which is provocative in the sense that it puts some popular views amongst Swiss geologists, including those of Martin's, into question. Knowing that Martin always liked and promoted lively discussion, we feel that this contribution by one of his former students and co-workers (Affolter et al. $2008)$ is very appropriate in this context. Hindle (2008) expands the discussion on the Alps-Jura system, while Gasser \& den Brok (2008) have a refreshingly new look at some structures in the famous Dachschiefer of Engi below the Glarus Thrust.
Herwegh et al. (2008) report on an excursion to the Glarus Thrust which took place in the fall of 2006, and at which Martin was supposed to participate. The report addresses many still controversial issues regarding the kinematics and dynamics of displacements along this famous thrust. This is followed by two complementary studies addressing calcite microfabrics and deformation mechanisms in naturally (Austin et al. 2008) and experimentally (delle Piane \& Burlini 2008) deformed calcite tectonites, illustrating innovative approaches towards a better understanding of the rheological properties of calcite rocks.

The series of papers by former students of Martin Burkhard starts with a contribution by Delacou et al. (2008) further analyzing neotectonic activity in the Western Alps in the light of geodetic data. The two following articles, written by two other former PhD students, deal with the Anti-Atlas (Ruiz et al. 2008; Robert-Charrue et al.). The last article discusses the structural pattern of a caldera in Teneriffa (Coppo et al. 2008). We are convinced that this series of articles will contribute to the ongoing debate on many hot topics, to which Martin Burkhard has contributed through his own work. A series of articles on seismic hazard assessment in honor of Martin Burkhard is planned to appear in a later issue of the Swiss Journal of Geosciences.

\section{REFERENCES}

Affolter, T., Faure J.-L., Gratier J.-P. \& Colletta, B. 2008: Kinematic models of deformation at the front of the Alps: new data from a map-view restoration. Swiss Journal of Geosciences, 101, 289-303.

Austin, N., Evans, B., Herwegh M. \& Ebert, A.: Strain Localization in the Morcles Nappe (Helvetic Alps, Switzerland). Swiss Journal of Geosciences, 101, 341-360.

Badertscher, N., Beaudoin, G., Therrin, R. \& Burkhard, M. 2002: Glarus overthrust: A major pathway for the escape of fluids out of the Alpine orogen. Geology 30/10, 875-878.

Burkhard, M. 1988: L'Helvétique de la bordure occidentale du Massif de l'Aar (évolution tectonique et métamorphique). Eclogae geologicae Helvetiae 81/1, 63-114.

Burkhard, M. 1990: Aspects of the large scale Miocene deformation in the most external part of the Swiss Alps (Subalpine Molasse to Jura fold belt). Eclogae geologicae Helvetiae 83/3, 559-583.

Burkhard, M.1993: Calcite twins, their occurence, appearance and significance as tectonicstress/strain markers: a review. Journal of Structural Geology 15/3-5, 351-368.

Burkhard, M. \& Kerrich, R. 1988: Fluid regimes in the deformation of the Helvetic nappes, Switzerland, as inferred from stable isotope data. Contributions to Mineralogy and Petrology 99, 416-429.

Burkhard, M. \& Sommaruga, A. 1998: Evolution of the western Swiss Molasse basin: structural relations with the Alps and the Jura belt. In: Mascle, A. et al. (Eds.): Foreland Basins of the Western Europe. Geological Society of London Special Publications 134, 279-298.

Burkhard, M., Caritg, S., Helg, U., Robert-Charrue, Ch. \& Soulaimani, A. 2006: Tectonics of the Anti-Atlas system. In: Frizon de Lamotte, D. et al. (Eds.): Some recent developments on the Maghreb geodynamics. Comptes Rendues des Geosciences Special Volume 338/1-2,11-24.

Challandes N., Marquer D. \& Villa I.M. 2008: P-T-t modelling, fluid circulation, and ${ }^{39} \mathrm{Ar}-{ }^{40} \mathrm{Ar}$ and $\mathrm{Rb}-\mathrm{Sr}$ mica ages in the Aar Massiv shear zones (Swiss Alps). Swiss Journal of Geosciences, 101, 269-288.

Coppo, N., Schnegg P.-A., Falco,P. Costa, R. \& Burkhard, M. 2008: Structural pattern of the western Las Cañadas caldera, Tenerife (Canary Islands). Swiss Journal of Geosciences, 101, 409-413. 
Delacou, B., Sue, Ch., Champagnac, J.D. \& Burkhard, M. 2004: Present-day geodynamics in the bend of the western and central Alps as constrained by earthquake analysis. Geophysical Journal International 158, 753-774.

Delacou, B., Sue, Ch., Nocquet J.-M., Champagnac J.-D., Allanic, C. \& Burkhard, M. 2008: Quantification of strain rate in the Western Alps using geodesy. Swiss Journal of Geosciences, 101, 377-385.

Delle Piane, C. \& Burlini, L.: Influence of strain history on the mechanical and micro-fabric evolution of calcite rocks: insights from torsion experiments. Swiss Journal of Geosciences, 101, 361-375.

Gasser D. \& Den Brok B.: Tectonic evolution of the Engi Slates, Glarus Alps, Switzerland. Swiss Journal of Geosciences, 101, 311-322.

Herwegh, M., Hürzeler J.-P., Pfiffner O.A., Schmid S.M., Abart R., \& Ebert A. 2008: Excursion guide and report of a field trip of the Swiss Tectonic Studies Group (Swiss Geological Society, 14.-16. 09. 2006). Swiss Journal of Geosciences, 101, 323-340.

Hindle, D. 2008: How hard were the Jura mountains pushed? Swiss Journal of Geosciences, 101, 305-310.

Hindle, D., Besson, O. \& Burkhard, M. 2000: A model of displacement and strain for arc-shaped moutain belts applied to the Jura arc. Journal of Structural Geology 22, 1285-1296.

Hürzeler, J.P. \& Abart R. 2008: Fluid flow and rock alteration along the Glarus thrust. Swiss Journal of Geosciences, 101, 251-268.

Robert-Charrue, Ch. \& Burkhard M. 2008: Inversion tectonics, interference pattern and extensional fault-related folding in the Eastern Anti-Atlas, Morocco. Swiss Journal of Geosciences, 101,397-408.

Ruiz, G.M.H., Helg, U., Negro, F., Adatte, T. \& Burkhard, M. 2008: Illite crystallinity patterns in the Anti-Atlas of Morocco. Swiss Journal of Geosciences, 101, 387-395.

\section{LIST OF MAJOR PUBLICATIONS BY MARTIN BURKHARD AND CO-WORKERS}

Burkhard, M. 1986: Déformation des calcaires de l'Helvétique de la Suisse occidentale (Phénomènes, mécanismes et interprétations tectoniques). Revue Géologie Dynamique et de Géographie Physique 27/5, 281-301.

Fischer, G., Schnegg, P.A., Ma, J., Müller, I. \& Burkhard, M. 1987: Etude VLR-F du remplissage quaternaire de la Vallée de Gastern, Alpes Bernoises, Suisse. Eclogae geologicae Helvetiae 80/3, 773-787.

Pfiffner, O.A. \& Burkhard, M. 1987: Determination of paleo-stress axes orientations from fault, twin and earthquake data. Annales Tectonicae 1/1, 48-57.

Burkhard, M. 1988: L'Helvétique de la bordure occidentale du massif de l'Aar (évolution tectonique et métamorphique). Eclogae geologicae Helvetiae 81/1, 63-114.

Burkhard, M. 1988: Horizontalschnitt des Helvetikums der Westschweiz auf $2500 \mathrm{~m}$ zwischen Mt Blanc und Aar-Massiv (Rawildepression). Geologische Berichte der Landeshydrologie und -geologie 4,34 pp.

Burkhard, M. \& Kerrich, R. 1988: Fluid regimes in the deformation of the Helvetic nappes, Switzerland, as inferred from stable isotope data. Contributions to Mineralogy and Petrology 99, 416-429.

Burkhard, M. \& Kalkreuth, W. 1989: Coalification in the northern Wildhorn nappe and adjacent units, western Switzerland. Implications for tectonic burial histories. International Journal of Coal Geology 11/1, 47-64.

Burkhard, M. 1990: Aspects of the large-scale Miocene deformation in the most external part of the Swiss Alps (Subalpine Molasse to Jura fold belt). Eclogae Geologicae Helvetiae 83/3, 559-583.

Burkhard, M. 1990: Ductile deformation mechanisms in micritic limestones naturally deformed at low temperatures $\left(150-350^{\circ} \mathrm{C}\right)$. In: Knipe, R.J. \& Rutter, E.H.J. (Eds.): Deformation Mechanisms, Rheology and Tectonics. Geological Society London Special Publications 54, 241-257

Burkhard, M. \& Kerrich, R. 1990: Fluid-rock interactions during thrusting of the Glarus nappe - evidence from geochemical and stable isotope data. Schweizerische Mineralogische und Petrographische Mitteilungen 70, $77-82$.

Schaer, J.-P., Burkhard, M., Tschanz, X., Gubler, E. \& Mathier, J.-F. 1990: Morphologie, contraintes et déformations dans le Jura central interne. Bulletin Societé Neuchâteloise des Sciences Naturelles 113,30-50.
Marquer, D. \& Burkhard, M. 1992: Fluid circulation, progressive deformation and mass-transfer processes in the upper crust: examples of basementcover relationships in the external cristalline massifs (Central Alps, Switzerland). Journal of Structural Geology 14/8, 1047-1057.

Burkhard, M., Kerrich, R., Maas, R.J. \& Fyfe, W.S. 1992: Stable and Sr-isotope evidence for fluid advection during thrusting of the Glarus nappe (Swiss Alps). Contributions to Mineralogy and Petrology 112, 293 311.

Burkhard, M.1993: Calcite twins, their geometry, appearance, significance as stress/strain markers and indicators of tectonic regime, a review. Journal of Structural Geology 15/3-5, 351-368.

Huon, S., Burkhard, M. \& Hunziker, J.C. 1994: Mineralogical, K-Ar, stable and $\mathrm{Sr}$ isotope systematics of $\mathrm{K}$-white micas during very low grade metamorphism of limestones (Helvetic nappes, western Switzerland). Chemical Geology 113, 347-376.

Henry, C., Burkhard, M. \& Goffé, B. 1996: Evolution of synmetamorphic veins and their wallrocks through a Western Alps transect: no evidence for large-scale fluid flow. Stable isotope, major- and trace-element systematics. Chemical Geology 127, 81-109.

Maurer, H.R., Burkhard, M. Deichmann, N. \& Green, A.G. 1997: Active tectonism in the central Alps: contrasting stress regimes north and south of the Rhone Valley. Terra Nova 9/2, 91-94.

Sommaruga, A. \& Burkhard, M. 1997: Jura Mountains; interpretation of seismic lines across the rhomb shaped Val-de-Ruz Basin (internal Folded Jura). In: Pfiffner, O.-A. et al. (Eds.): Deep structure of the Swiss Alps, results of NFP 20, Birkhäuser Verlag Basel, 45-53.

Badertscher, N. \& Burkhard, M. 1998: Inversion alpine du graben PermoCarbonifère de Salvan-Dorénaz et sa relation avec le chevauchement de la nappe de Morcles sus-jacente. Eclogae geologicae Helvetiae 91, 359-373.

Burkhard, M. \& Sommaruga, A. 1998: Evolution of the western Swiss Molasse basin: structural relations with the Alps and the Jura belt. In: Mascle, A. et al. (Eds.): Foreland Basins of the Western Europe. Geological Society of London Special Publications 134, 279-298.

Burkhard, M., Atteia, O., Sommaruga, A., Gogniat, S. \& Evard, D. 1998: Tectonique et hydrogéologie dans le Jura Neuchâtelois. Eclogae geologicae Helvetiae 91/1,177-183.

Hindle, D. \& Burkhard, M. 1999: Strain, displacement and rotation associated with the formation of curvature in fold belts; the example of the Jura arc. Journal of Structural Geology 21/8-9, 1089-1101.

Badertscher, N.P. \& Burkhard, M. 2000: Brittle-ductile deformation in the Glarus thrust Lochseiten (LK) calc-mylonite. Terra Nova 12/6, 281188.

Hindle, D., Besson, O. \& Burkhard, M. 2000: A model of displacement and strain for arc-shaped mountain belts applied to the Jura arc. Journal of Structural Geology 22/9, 1285-1296.

Burkhard, M. \& Badertscher, N. 2001: Finite strain has no influence on the illite crystallinity of tectonized Eocene limestone breccias of the Morcles nappe, Swiss Alps. Clay Minerals 36/2,171-180.

Burkhard, M., \& Goy-Eggenberger, D. 2001: Near vertical iso-illite-crystallinity surfaces cross-cut the recumbent fold structure of the Morcles nappe, Swiss Alps. Clay Minerals 36/2,159-170.

Dick, P. \& Burkhard, M. 2001: Magnetic anisotropy and X-ray diffraction study of clay minerals in the decollement horizons of the western Helvetic nappes, SW Switzerland. Clay Minerals 36/2, 181-196.

Abart, R., Badertscher, N., Burkhard, M. \& Povoden E. 2002: Oxygen, carbon and strontium isotope systematics in two profiles across the Glarus thrust: implications for fluid flow. Contributions to Mineralogy and Petrology 143, 192-208.

Badertscher, N.P., Abart, R., Burkhard, M. \& McCaig, A. 2002: Fluid flow pathways along the Glarus overthrust derived from stable and Sr-isotope patterns. American Journal of Science 302/6, 517-547.

Badertscher, N.P., Beaudoin, G., Therrien, R. \& Burkhard, M. 2002: Glarus overthrust: a major pathway for the escape of fluids out of the Alpine orogen. Geology 30/10, 875-878.

Champagnac, J.-D., Sue, C., Delacou, B. \& Burkhard, M. 2003: Brittle orogenparallel extension in the internal zones of the Swiss Alps (South Valais). Eclogae geologicae Helvetiae 96/2, 325-338. 
Caritg, S., Burkhard, M., Ducommun, R., Helg, U., Kopp, L. \& Sue, C. 2004: Fold interference patterns in the late Palaeozoic Anti-Atlas belt of Morocco. Terra Nova $16 / 1,27-37$.

Champagnac, J.-D., Sue, C., Delacou, B. \& Burkhard, M. 2004: Brittle deformation in the inner NW Alps: from early orogen-parallel extrusion to late orogen-perpendicular collapse. Terra Nova 16/4, 232-242.

Delacou, B., Sue, C. Champagnac, J.-D. \& Burkhard, M. 2004: Present-day geodynamics in the bend of the western and central Alps as constrained by earthquake analysis. Geophysical Journal International 158/2, 753-774.

Ferrill, D.A., Morris, A.P., Evans, M.A., Burkhard, M., Groshong, R.H. Jr. \& Onasch, C.M. 2004: Calcite twin morphology: a low-temperature deformation geothermometer. Journal of Structural Geology 26/8, 1521-1529.

Grosjean, G., Sue, C. \& Burkhard, M. 2004: Late neogene extension in the vicinity of the Simplon fault zone (central Alps, Switzerland). Eclogae geologicae Helvetiae 97/1,33-46.

Helg, U., Burkhard, M., Caritg, S. \& Robert-Charrue, C. 2004: Folding and inversion tectonics in the Anti-Atlas of Morocco. Tectonics 23/4, 4006-4017.

Valley, B., Burkhard, M. \& Schnegg, P.-A. 2004: Dépliage 3-D des anticlinaux bordant le synclinal fermé de la vallée des Ponts, Jura central, Suisse. Eclogae geologicae Helvetiae 97/2, 279-291.

Delacou, B., Deichmann, N., Sue, C., Thouvenot, F., Champagnac, J.-D. \& Burkhard, M. 2005: Active strike-slip faulting in the Chablais area (NW Alps) from earthquake focal mechanisms and relative locations. Eclogae geologicae Helvetiae 98/2,189-199.

Delacou, B., Sue, C., Champagnac, J.-D. \& Burkhard, M. 2005: Origin of the current stress field in the Western/Central Alps; role of gravitational re-equilibration constrained by numerical modelling. In: Gapais-D et al. (Eds.): Deformation mechanisms, rheology and tectonics; from minerals to the lithosphere. Geological Society of London Special Publications 243, 295-310.

Burkhard, M., Caritg, S., Helg, U., Robert-Charrue, Ch. \& Soulaimani, A. 2006: Tectonics of the Anti-Atlas system. In: Frizon de Lamotte, D. et al. (Eds.): Some recent developments on the Maghreb geodynamics. Comptes Rendues des Geosciences Special Volume 338/1-2,11-24.
Persoz, F. \& Burkhard, M. 2006: Histoire géologique de la région de Lignières. In: "Lignière. Un village aux confins de trois Etats". Editions Gilles Attinger SA Hauterive, Suisse, 11-18.

Champagnac, J.-D.,Sue, C., Delacou, B., Tricart,P., Allanic, C. \& Burkhard, M. 2006: Miocene lateral extrusion in the inner Western Alps revealed by dynamic fault analysis. Tectonics 25/3, TC3014.

Champagnac, J.D., Delacou, B., Tricart, P., Sue, C., Burkhard, M., Allanic, C. 2006: Regional brittle extension in Quaternary sediments of Lanslebourg (Haute-Maurienne valley, Western Alps). Bulletin de la Société Géologique de France 177/4, 215-223.

Graf, A.A., Strasky, S., Ivy-Ochs, S., Akcar, N., Kubik, P.W., Burkhard, M. \& Schlüchter, Ch. 2007: First results of cosmogenic dated pre-last glaciation erratics from the Montoz area, Jura Mountains, Switzerland. Quaternary International 164-165, 43-52.

Sue, C., Delacou, B., Champagnac, J.D., Allanic, C., Burkhard M. 2007. Aseismic deformation in the Alps: GPS vs. seismic strain quantification. Terra Nova 19, 182-188.

Sue C., Delacou, B., Champagnac J.D., Allanic, C., Tricart, P., \& Burkhard, M. 2007: Extensional neotectonics around the bend of the Western/Central Alps: an overview. International Journal of Earth Sciences 96, 11011129.

Schaer, J-P., Robert-Charrue, C. \& Burkhard, M. 2008: Val-de-Travers, géologie et évolution morphologique. In: Val-de-Travers, une région, une identité, Ed. Gilles Attinger, Hauterive, Suisse, 9-36.

Soulaimani, A. \& Burkhard, M. 2008: The Anti-Atlas chain (Morocco): the southern margin of the Variscan belt along the edge of the West African craton. Geological Society, London, Special Publications, 297, 433-452. doi: $10.1144 /$ SP297.20.

Manuscript received April 1, 2008

Revision accepted May 15, 2008

Editorial Handling: S. Bucher 